Hydrol. Earth Syst. Sci., 17, 3921-3936, 2013

www.hydrol-earth-syst-sci.net/17/3921/2013/

doi:10.5194/hess-17-3921-2013

(c) Author(s) 2013. CC Attribution 3.0 License.

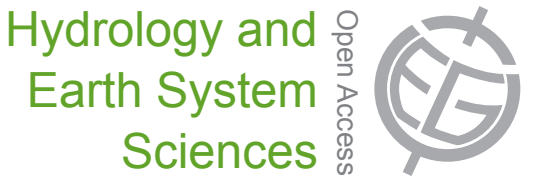

\title{
Precipitation and snow cover in the Himalaya: from reanalysis to regional climate simulations
}

\author{
M. Ménégoz, H. Gallée, and H. W. Jacobi \\ 38041 Grenoble, France \\ Correspondence to: M. Ménégoz (martin.menegoz@lgge.obs.ujf-grenoble.fr) \\ Received: 31 May 2013 - Published in Hydrol. Earth Syst. Sci. Discuss.: 17 June 2013 \\ Revised: 3 September 2013 - Accepted: 3 September 2013 - Published: 15 October 2013
}

CNRS and UJF Grenoble 1, Laboratoire de Glaciologie et Géophysique de l'Environnement (LGGE, UMR5183),

\begin{abstract}
We applied a Regional Climate Model (RCM) to simulate precipitation and snow cover over the Himalaya, between March 2000 and December 2002. Due to its higher resolution, our model simulates a more realistic spatial variability of wind and precipitation than those of the reanalysis of the European Centre of Medium range Weather Forecast (ECMWF) used as lateral boundaries. In this region, we found very large discrepancies between the estimations of precipitation provided by reanalysis, rain gauges networks, satellite observations, and our RCM simulation. Our model clearly underestimates precipitation at the foothills of the $\mathrm{Hi}-$ malaya and in its eastern part. However, our simulation provides a first estimation of liquid and solid precipitation in high altitude areas, where satellite and rain gauge networks are not very reliable. During the two years of simulation, our model resembles the snow cover extent and duration quite accurately in these areas. Both snow accumulation and snow cover duration differ widely along the Himalaya: snowfall can occur during the whole year in western Himalaya, due to both summer monsoon and mid-latitude low pressure systems bringing moisture into this region. In Central Himalaya and on the Tibetan Plateau, a much more marked dry season occurs from October to March. Snow cover does not have a pronounced seasonal cycle in these regions, since it depends both on the quite variable duration of the monsoon and on the rare but possible occurrence of snowfall during the extramonsoon period.
\end{abstract}

\section{Introduction}

The Himalayan Mountains are the source of many major rivers in Central Asia with drainage basins reaching a total area of $6.7 \times 10^{9} \mathrm{~km}^{2}$, and supplying water to more than 1.2 billion people (Revenga et al., 2003). Local populations are very dependent on these resources, for drinkable water, but also for hydro-electric power generation and agricultural activities, which is one of the main sectors of local economy. Therefore, it appears essential to understand both the contributing components and the evolution of this resource. Monsoon constitutes the main source of precipitation in this region. Bookhagen and Burbank (2010) found it to be responsible for more of $80 \%$ of annual rainfall in the central Himalaya and on the Tibetan Plateau. However, according to this study, this contribution is smaller in the western and in the eastern parts of the Himalaya, where monsoon and mid-latitude low pressure systems produce approximately the same amounts of precipitation. Snowmelt and glacier melt are also a major source of water, which is stocked in the mountains during cold periods and is returned down during melting periods. Immerzeel et al. (2009) estimated this input to exceed $50 \%$ of the total annual discharge in the far western (Indus) catchments, 30\% in the Brahmaputra basin, and 10\% elsewhere. Most of the studies performed to evaluate the hydrological cycle in this region have used "Snowmelt Runoff Models" (SRM, e.g. Shrestha et al., 2012). Such models need as inputs an estimation of precipitation and snow cover. To simulate the present hydrological budget in such regions, precipitation is often derived from remotely sensed observations like, for example, the Tropical Rainfall Measuring Mission (TRMM, Kummerow et al., 1998, 2000). Precipitation can 
also be derived from global reanalysis data (ECMWF, European Centre for Medium-range Weather Forecasts, Dee et al., 2011) or from gridded observational data (APHRODITE, Yatagai et al., 2012). However, all these estimations of the precipitation rates in the Himalaya differ widely from one product to another (e.g. Palazzi et al., 2013). Such estimations are also generally very uncertain over mountainous areas: This has been found for TRMM data, which are significantly biased over the Tibetan Plateau (Yin et al., 2008). In the same region, Ma et al. (2009) found also strong biases in the reanalysed precipitation, which they attributed to the lack of observations in high altitude areas. For the same reason, Yatagai et al. (2012) explained that the gridded APHRODITE precipitation has to be taken very carefully in the Himalaya, even if this observational data seems to be one of the most realistic as it is based on many surface rain gauges observations. Overall, these products provide an estimation of liquid precipitation, but it is well known that snowfall is hugely under-estimated, both by remote sensing and by surface rain gauges. In this context, atmospheric models appear to be useful tools to evaluate solid precipitation. Roesch (2006) and Brutel-Villemet et al. (2013) have shown that current existing Global Circulation Models (GCM) are constantly improving their capacities to describe the snowcover over most parts of continental surfaces. Therefore, we can also expect them to simulate better snowfall. However, these studies have also stressed that such models are generally strongly biased over mountainous areas, in particular over the Himalaya. A large part of the biases is induced by the coarse resolution of the GCMs. As they are applied over limited area domains, Regional Circulation Models (RCM) are generally used with finer resolution. Sabin et al. (2012) showed that an increase of the model resolution over Central Asia significantly increased the model capacity to simulate precipitation over the Himalaya during the monsoon. Performing multi-year simulations appears essential to identify significant errors in RCMs (Fu et al., 2005). Following this recommendation, Polanski et al. (2010) showed that precipitation simulated with a RCM from 1958 to 2001 over the Indian monsoon region is in better agreement with gridded observations than the ERA40. Feng and Fu (2006) showed that cloud schemes, which are generally more detailed in the RCMs in comparison with those used in the GCMs, are essential to accurately describe precipitation in the Indian monsoon region. Mark and Hank (2009) and Akhtar et al. (2009) used 50-km gridded RCMs outputs to force hydrological models applied at even higher resolutions $(\sim 1 \mathrm{~km})$. Their results showed promising applications of RCMs outputs, limited however by the performances of the RCMs, which sometimes still show large biases in comparison with observations, in particular over the Indian monsoon region (e.g. Lucas-Picher et al., 2011). Parts of these biases are due to the coarse resolution, which does not allow the simulation of local atmospheric processes. Going down to finer and finer scales, Maussion et al. (2011) used a RCM with different resolutions over the Tibetan Plateau to simulate precipitation during a one-month period. Forced at the lateral boundaries with atmospheric reanalyses, the model simulates quite well both liquid and solid precipitation: using comparisons with weather station measurements, the authors of this study estimate that their simulation gave better results than the TRMM data. Their model was also found to accurately describe the snow-cover extent. However, the high computational time needed to perform such simulation limits the possibility to realise multi-annual simulations. Indeed, such an approach appears to be very useful to quantify when and how much snow is accumulated in mountainous areas, where few observational data is available. To deal with small scale surface processes over longer periods with a standard RCM resolution, Dimri and Niyogi (2013) applied RCMs with a sub-grid scale representation of surface energy fluxes, which were computed at $10 \mathrm{~km}$ resolution whereas the atmospheric variables were only resolved at $60 \mathrm{~km}$ resolution. Recently, and due to permanently increasing computational resources, Dimri et al. (2013) applied two RCMs over eighteen years with a $25 \mathrm{~km}$ grid resolution in western Himalaya. Theses two last studies showed that the dynamical downscaling with RCMs can be used to simulate regional climate at the mountain scale, but also to reproduce local meteorological events. However, even such a pioneering approach does not allow to estimate correctly the separation between liquid and solid phase of the precipitation, limiting therefore the possible hydrological and glaciological applications. Our study is dedicated to the analysis of precipitation and snow cover over central and eastern Himalaya, applying a RCM centred on the Nepal region. Due to high computational cost, we performed a simulation for a period of $3 \mathrm{yr}$. Nevertheless, we expect this model to provide a first estimation of solid precipitation and snow depth in this region, as it is based on an optimised cloud microphysics scheme and a detailed surface snow scheme.

After the introduction exposed in Sect. 1, we present in Sect. 2 the RCM and the experimental setup that we used to perform our simulation. In Sect. 3, we describe the observational datasets used for the model validation. In Sect. 4, we compare the atmospheric circulation described in the reanalyses with those modelled with the RCM. In Sect. 5, we focus on the ability of our model to simulate precipitation during the monsoon and the extra-monsoon periods. In Sect. 6, we validate the simulated snow cover using satellite products for the snow cover extent, which are clearly more reliable than the observations of precipitation. Finally, we analyse the snow accumulation over different regions of the Himalaya, before presenting the main conclusions in Sect. 7. 


\section{The Model Atmospheric Regional (MAR)}

\section{Model description}

The model MAR (Modèle Atmosphérique Régional) used in this study is a hydrostatic primitive equation model in which the vertical coordinate is the normalised pressure. Details of the dynamics and the cloud microphysical scheme can be found in Gallée and Schayes (1994), Gallée (1995) and Gallée et al. (2001, 2005). MAR includes six prognostic equations for specific humidity, cloud droplet concentration, cloud ice crystals (concentration and number), concentration of precipitating snow particles and rain drops. Ice microphysical processes are included based on the work of Lin et al. (1983), while the ice nuclei concentration is parameterized according to Meyers et al. (1992). The conversion from cloud ice crystals to precipitating snow and the prognostic equation for the ice crystal number are based on Levkov et al. (1992). Cloud radiative properties are computed from the concentration of cloud droplets and cloud ice crystals (Ebert and Curry, 1992). Solar and infrared radiation schemes are provided by Fouquart and Bonnel (1980) and Morcrette (1984, 2002). Originally designed for polar regions, MAR has been adapted to tropical regions by implementing the convective adjustment scheme of Bechtold et al. (2001). Further details of the implementation of processes in the tropics in MAR can be found in Gallée et al. (2004) and Messager et al. (2004). This upgraded model version has been validated regarding the simulation of the African monsoon (Gallée et al., 2004; Vanvyve et al., 2008).

The simulated domain considered for this study covers a part of the Himalayan mountain range, from $79^{\circ} \mathrm{E}$ to $95^{\circ} \mathrm{E}$ and $22^{\circ} \mathrm{N}$ to $32^{\circ} \mathrm{N}$ (see Fig. 1.). The horizontal grid spacing is $20 \mathrm{~km}$ and the vertical dimension is represented by 40 vertical levels irregularly spaced with a finer resolution close to the surface (first level $10 \mathrm{~m}$ above the ground level). The atmospheric variables are initialised and forced every $6 \mathrm{~h}$ at the lateral boundaries using the ERA-INTERIM reanalysis available at a resolution of about $80 \mathrm{~km}$ (Dee et al., 2011). Details of the boundary forcing can be found in Marbaix et al. (2003). In all figures presented here, we show the entire domain of simulation to clearly visualize the buffer zone, which reaches approximately 100 to $200 \mathrm{~km}$. The MAR is coupled to the one-dimensional land surface scheme SISVAT (Soil Ice Snow Vegetation Atmosphere Transfer, De Ridder and Schayes, 1997; Gallée et al., 2001) in which water and energy budgets are solved independently for soil and vegetation. Surface type and Leaf Area Index (LAI) are derived from MODIS product, available from March 2000 to present-day, with a temporal resolution of 8 days. The surface scheme includes snow (Gallée et al., 2001) and an ice module (Lefebre et al., 2003). The snow model is a multi-layer model including prognostic equations for temperature, mass, water content and snow properties (dendricity, sphericity and size). The evolution of the snowpack properties is parameterized according to Brun et al. (1992). In our Himalayan simulation, blowing snow is not taken into account as it is generally done for MAR simulations performed over Antarctica (e.g. Gallée et al., 2005). The coupling of SISVAT with the atmosphere is performed through the exchange of radiative (solar, infrared) fluxes and turbulent fluxes of momentum and heat (sensible and latent).

MAR simulations were performed from March 2001, when MODIS data first become available, until December, 2003 , yielding approximately $3 \mathrm{yr}$ of simulation. The first month of simulation has to be considered carefully, as it consists in a spin-up period.

\section{Observational data}

Facing the human, environmental and scientific challenges associated with the evolution of the water resources, different observational networks have been developed to study the evolution of the cryosphere and the hydrosphere. Most of our paper is based on comparisons between model outputs and such observations of precipitation and snow cover. The products that we found relevant for the Himalayan region are listed in Table 1.

\section{Moisture flux and wind fields}

As explained in the introduction, two main weather regimes bring moisture over the Himalaya. Figure 1 shows the vertical integration of the wind multiplied by the specific humidity, to give an idea of the origin of moisture generating precipitation over our domain of simulation during the monsoon 2001 (JJAS) and the extra-monsoon period 20012002 (ONDJFMAM). The monsoon period is associated with a strong cyclonic circulation inducing a general northward transport of humidity over the Himalaya and the Tibetan Plateau (Fig. 1a for the ERA-INTERIM). This transport is more oriented eastward during the extra-monsoon period (Fig. $1 \mathrm{~b}$ for the ERA-INTERIM). The flux of moisture in the MAR simulation (Fig. 1c and d) is clearly modified compared to the ERA-INTERIM data. Due to the higher resolution, $(20 \mathrm{~km}$ versus $80 \mathrm{~km}$ for the reanalysis), we see a strong spatial heterogeneity over the mountains of Nepal, Sikkim and Bhutan, which is certainly more realistic, since the complex topography of this region impacts the atmospheric circulation. During the monsoon period, MAR simulates a very low flux of moisture over the Tibetan Plateau and over the eastern part of Himalaya (Sikkim, Bhutan and Arunachal Pradesh) in comparison with the ERA-INTERIM data, where large amount of moisture are transported northward. The difference between ERA-INTERIM and MAR simulation during the extra-monsoon period is more pronounced in the South of the Himalayan mountain range, where the simulated moisture flux is very low in comparison to those estimated with the ERA-INTERIM. Overall, the 
Table 1. Main characteristics of the observational and the reanalysis datasets used for comparisons with model outputs.

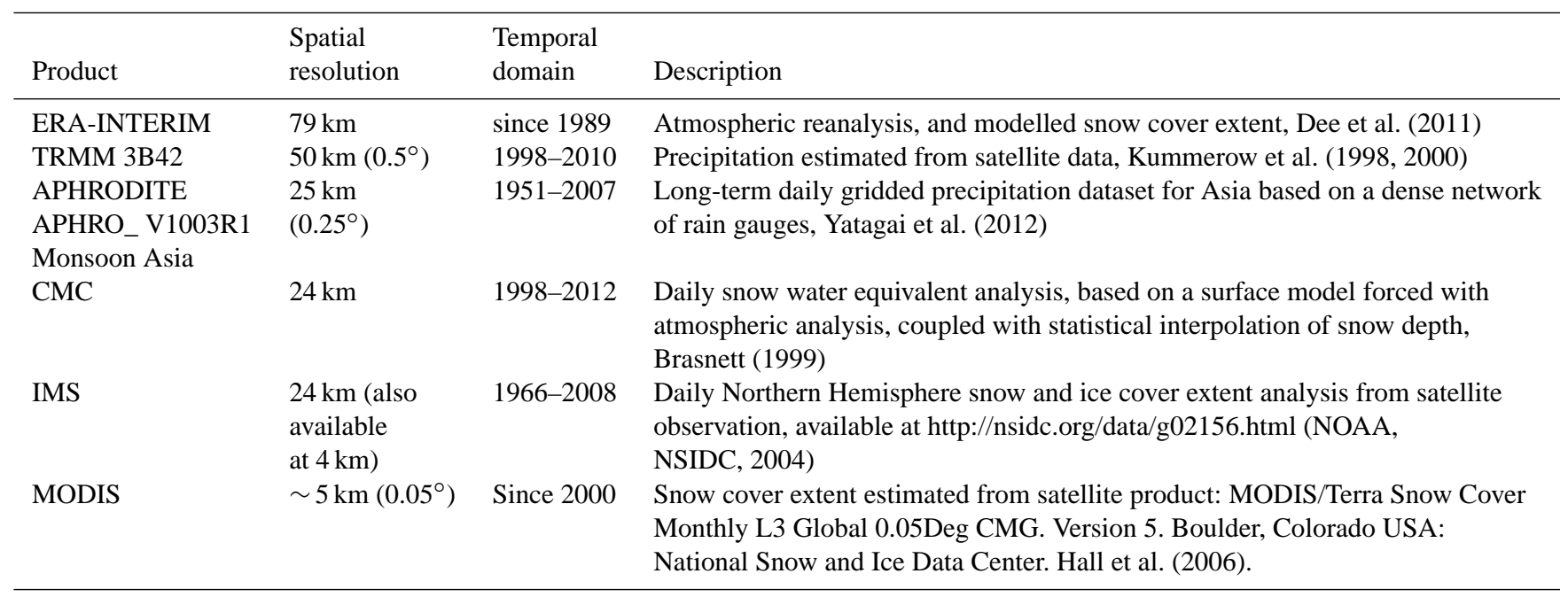

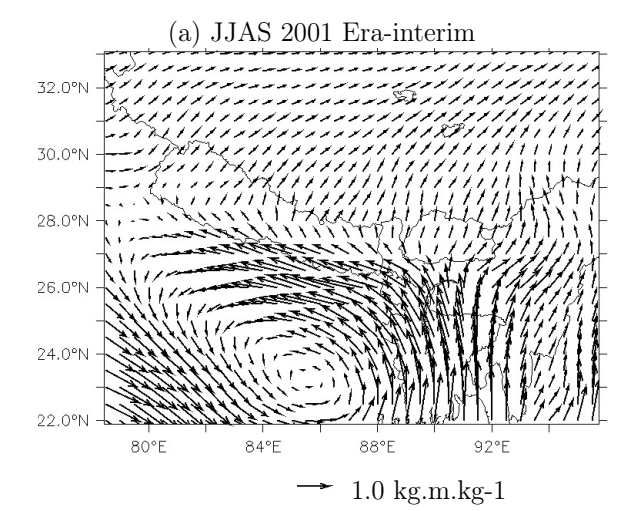

(c) JJAS 2001 MAR

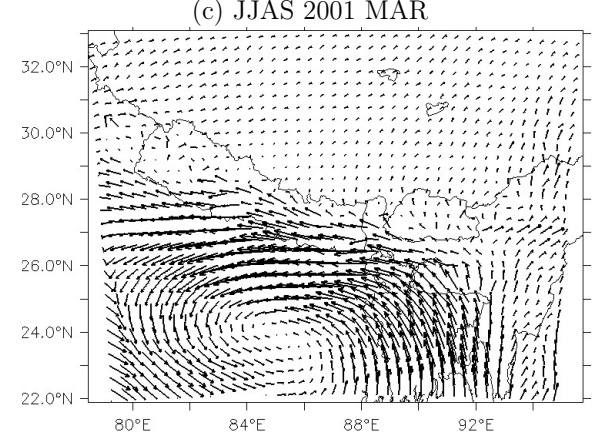

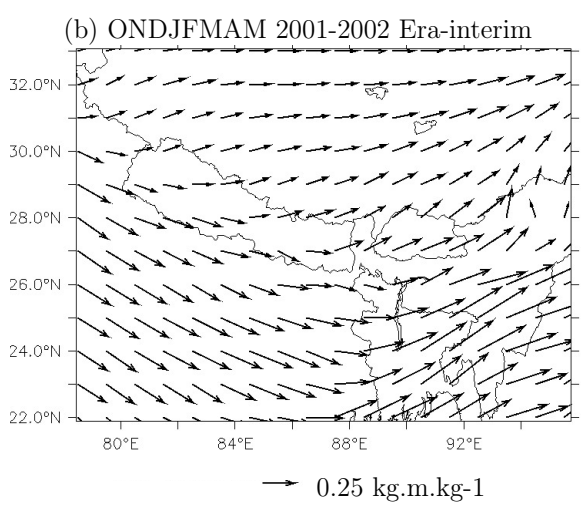

(d) ONDJFMAM 2001-2002 MAR

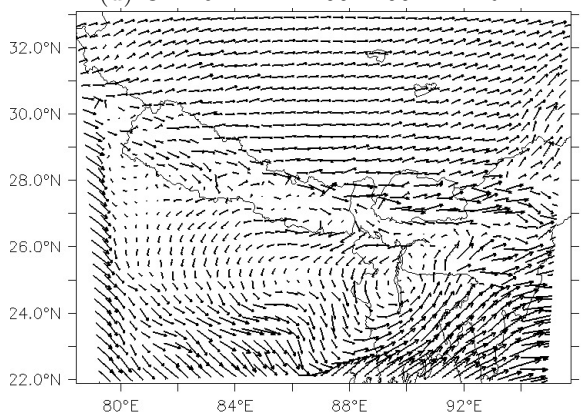

Fig. 1. Moisture flux $\left(\mathrm{kg} \mathrm{m} \mathrm{kg}^{-1} \mathrm{~s}^{-1}\right)$ defined as wind velocity multiplied by specific humidity: estimated from the ERA-INTERIM during (a) monsoon (JJAS) 2001, (b) extra-monsoon period (ONDJFMAM) 2001-2002, and simulated with MAR during (c) monsoon (JJAS) 2001 and (d) extra-monsoon period (ONDJFMAM) 2001-2002.

higher resolution of MAR in comparison with the ECMWF model translates into higher surface roughness and higher surface altitude in mountainous areas, which can slow and even divert the flux of moisture in these regions.

Figure 2 shows wind speed temporally averaged at $86^{\circ} \mathrm{E}$ from the ERA-INTERIM data and in the MAR simulation both for monsoon and extra-monsoon periods. In general, the subtropical jet stream does not affect the Himalayan region during the monsoon period (Fig. 2a). The southward shift of the subtropical jet in winter, which is clearly visible around $30^{\circ} \mathrm{N}$ (Fig. 2b), induces strong winds during this period. Averaged wind speed exceeds $40 \mathrm{~m} \mathrm{~s}^{-1}$ around 12000 a.s.1. (close to the tropopause), and reaches $10 \mathrm{~m} \mathrm{~s}^{-1}$ at the surface of the Tibetan Plateau and the Himalayan 


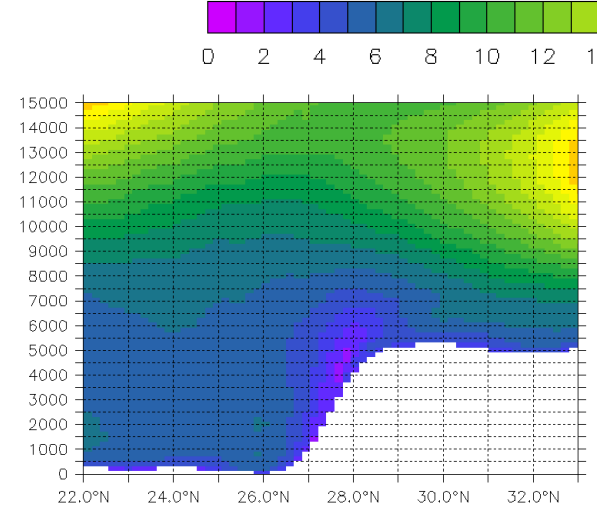

(a) JJAS 2001 Era-interim

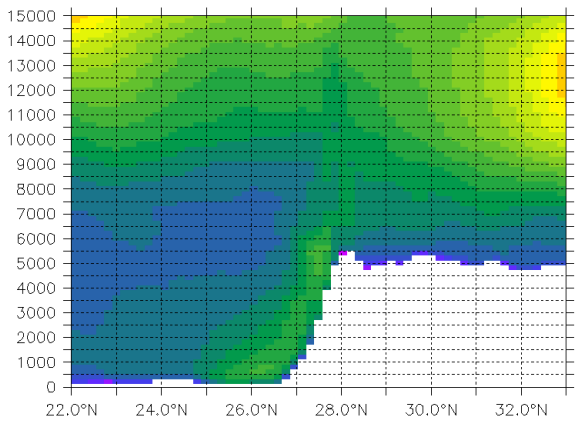

(c) JJAS 2001 MAR

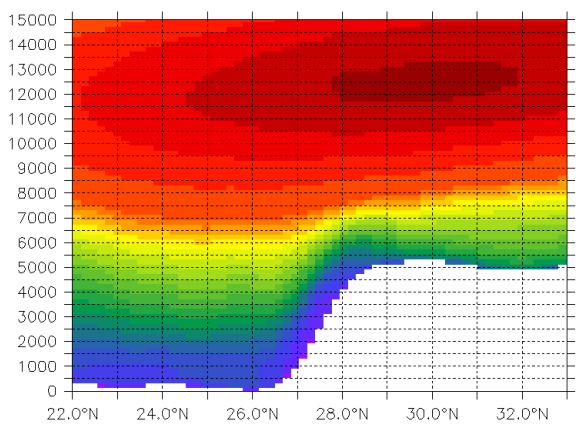

(b) ONDJFMAM 2001-2002 Era-interim

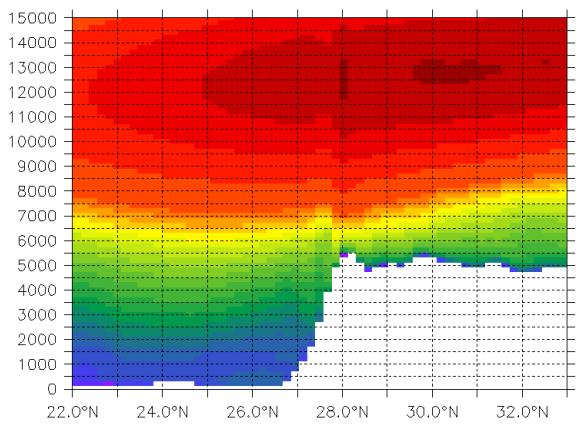

(d) ONDJFMAM 2001-2002 MAR

Fig. 2. Wind intensity temporally averaged at the longitude $86^{\circ}$ E: estimated from the ERA-INTERIM during (a) monsoon (JJAS) 2001, (b) extra-monsoon period (ONDJFMAM) 2001-2002, and simulated with MAR during (c) monsoon (JJAS) 2001 and (d) extra-monsoon period (ONDJFMAM) 2001-2002.

region. However, wind speed remains low over the North Indian plain during this period. In this region, wind increases to slightly higher values during the monsoon period. Three main notable differences are simulated with MAR in comparison with the ERA-INTERIM: (i) during the monsoon, the increase of resolution seems to orient the direction of the atmospheric flux at $86^{\circ} \mathrm{E}$ more westward and southward (Fig. 1c), inducing an acceleration of the flux at the southern side of the mountains (Fig. 2c). (ii) The higher resolution of MAR better reproduces the spatial heterogeneity of the surface height in the Himalayan region in comparison with the ECMWF model (Fig. 2b and d). Therefore, wind speed velocity is very heterogeneous both over the Himalaya and the Tibetan Plateau. Isolated grid points located at high altitude are generally more exposed to stronger winds whereas wind speed is smaller in the grid points located in depressions (Fig. 2d). (iii) During the extra-monsoon period, mountains generate gravity waves which affect the subtropical jet in the MAR simulation, whereas it not the case in the ERAINTERIM data. This is due to the surface topography, which is described more accurately in MAR than in the ECMWF model because of its higher resolution. Hence, in our regional simulation, the atmospheric circulation is affected up to the uppermost layers of the troposphere.

\section{Modelled and observed precipitation}

Figure 3 shows the monsoon 2001 total precipitation simulated with MAR (panel a), and deduced from the ERAINTERIM (panel c), TRMM (panel e) and APHRODITE (panel g) datasets (see their description in Table 1). Generally, monsoon precipitation is more intense in the south and in the east of the Himalaya. Such a pattern is related to the moisture flux shown in Fig. 1a. Monsoon precipitation exceeds averaged values of $500 \mathrm{~mm} \mathrm{month}^{-1}$ over Bangladesh and Arunachal Pradesh. During the same period, precipitation is very low, ranging from 10 to $50 \mathrm{~mm} \mathrm{month}^{-1}$ over most parts of the Tibetan Plateau. Monsoon precipitation reaches also very high values in some regions of the Himalayan mountain range, with values locally exceeding $500 \mathrm{~mm} \mathrm{month}^{-1}$. We found however very strong differences between the different estimations of precipitation shown in Fig. 3. 


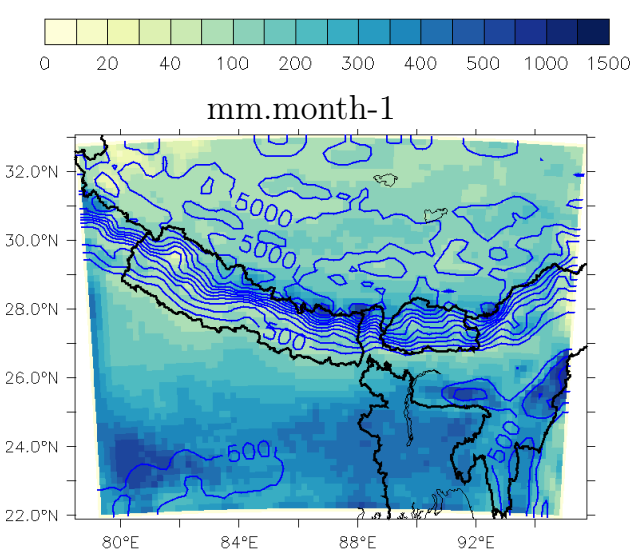

(a) MAR

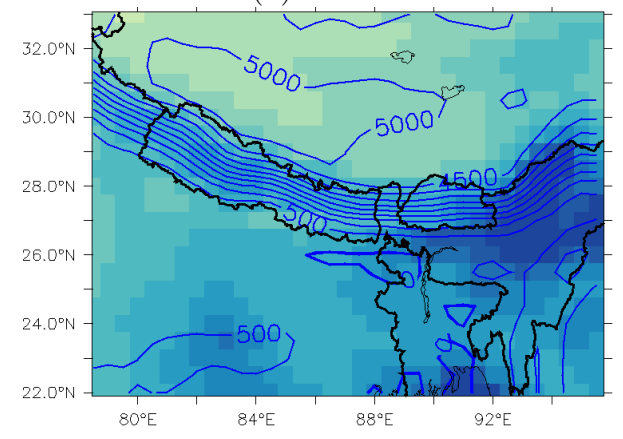

(c) ERA

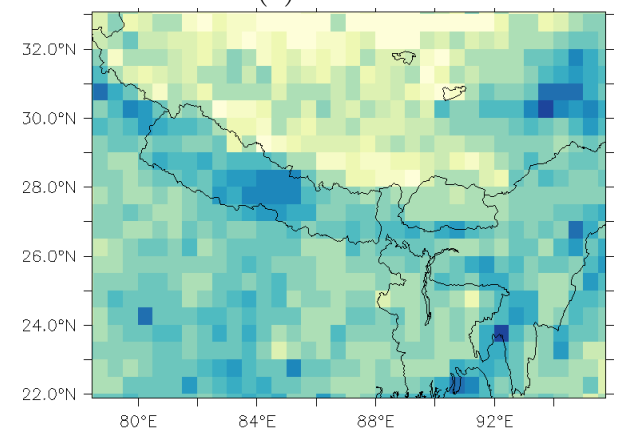

(e) TRMM

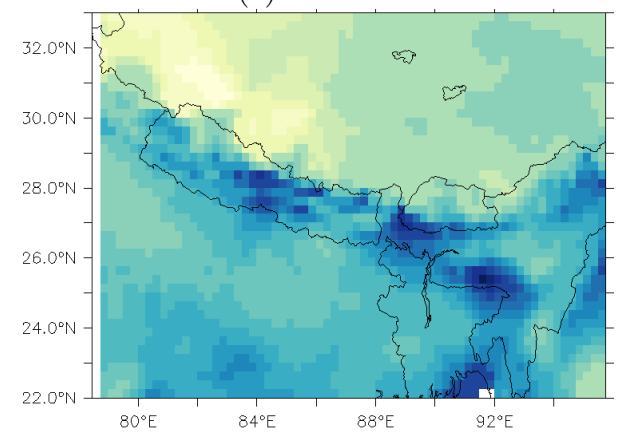

(g) APHRO

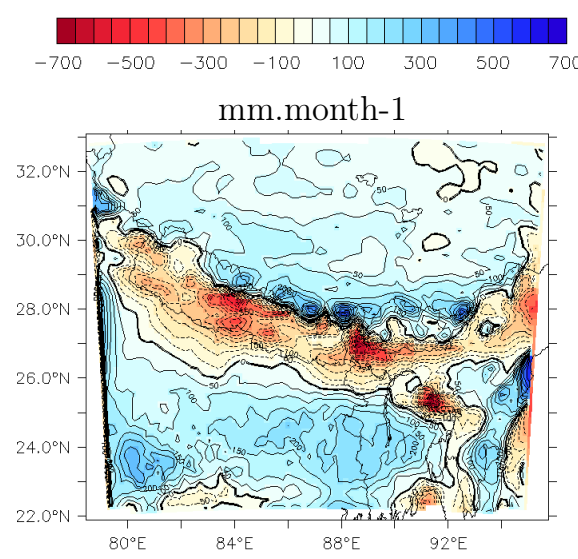

(b) MAR-APHRO

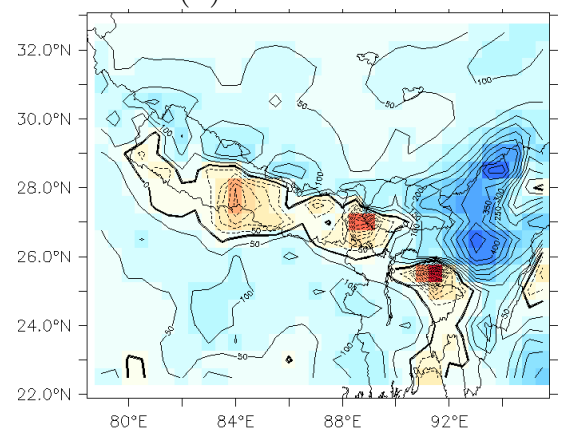

(d) ERA-APHRO

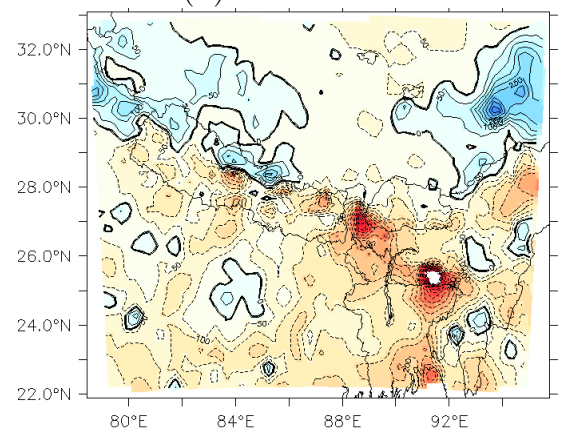

(f) TRMM-APHRO

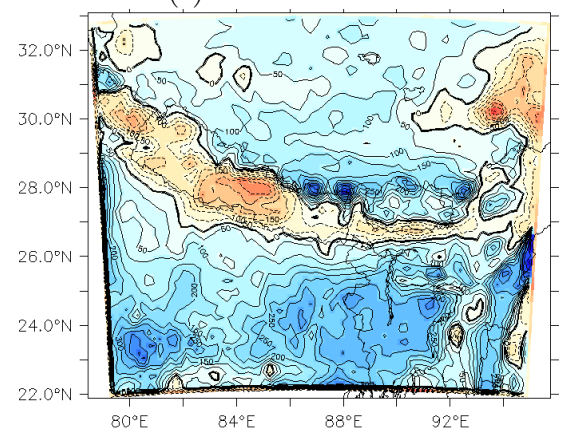

(h) MAR-TRMM

Fig. 3. Monsoon (JJAS) 2001 precipitation $\left(\mathrm{mm} \mathrm{month}^{-1}\right.$ ): (a) simulated with MAR, (c) estimated from ERA-INTERIM, (e) evaluated from TRMM, and (g) observed with APHRODITE network. Figures in the right column correspond to the differences (b) MAR-APHRODITE, (d) ERAINTERIM-APHRODITE, (f) TRMM-APHRODITE, and (h) MAR-TRMM. 
Regarding the MAR simulation, we clearly visualize the buffer zone that corresponds to the region where the humidity is constantly forced by the reanalyses, inducing unrealistic precipitation patterns. In the following, we exclude this buffer zone from our analysis. The spatial heterogeneity of precipitation observed in the APHRODITE network (Fig. 3g) is better reproduced in the MAR simulation (Fig. 3a) than in the ERA-INTERIM (Fig. 3c), in particular over the Himalaya, where the precipitation can vary by a factor of 10 within a distance of only some $\mathrm{km}$. Even with the improvements obtained with the MAR simulation compared to the ERA-INTERIM, some differences between rain gauge observations and modelled precipitation are particularly notable: The ERA-INTERIM estimation shows less precipitation on the southern slope of the Himalaya than the APHRODITE network (which we call in the following the "dry bias", see Fig. 3d). In contrast, on the northern slope and in the most eastern part of the Himalaya, precipitation is more abundant in ERA-INTERIM than in APHRODITE (which we call in the following the "humid biases", see Fig. 3d). It is quite difficult to verify the correct precipitation rate due to the difficulty to monitor hydrometeorology by in situ stations in these mountainous regions. As explained by Archer and Fowler (2004), such networks are often biased in altitude, as stations are generally located in valley floors, lower in altitude than the zones of maximum precipitation, located on mountains slopes and top. Nevertheless, we see that the supposed dry bias of the ERA-INTERIM on the southern slope (Fig. 3d) is further amplified in the MAR simulation (Fig. 3b). This is not the case in the supposed humid bias of the ERA-INTERIM in the most eastern part of the Himalaya, which is not reproduced in the MAR simulation. Yatagai et al. (2012) explained that the rain gauge network used to construct APHRODITE data is denser in the Indian plain and in the foothills of the Himalaya than in areas of high altitude. Therefore, we estimate that the "dry bias" in the MAR simulation is real, whereas the "humid bias" may not be an artefact of our model, due to the uncertainty of the APHRODITE network in these regions. This point is corroborated by the fact that commonly used rain gauges are well known to strongly underestimate solid precipitation (Goodison et al., 1998). As discussed in Sect. 1, TRMM data has also been found to underestimate precipitation over mountainous areas. This remotely sensed observation shows also precipitation rates lower in the foothill of the Himalaya than those measured with the APHRODITE network (Fig. 3f). Concerning precipitation in the most eastern part of Himalaya and Tibetan Plateau, both APHRODITE and MAR simulation show lower precipitation rates than TRMM and ERA-INTERIM data in this region. Once again, we have to be very careful when estimating which of these products is the closest to reality, considering their large uncertainties.

Figure 4 shows the total precipitation from October 2001 to May 2002 simulated with MAR (panel a), and estimated from the ERA-INTERIM (panel c), from TRMM (panel e) and from the APHRODITE network (panel g). In general, this period is characterised by very low precipitation rates over the Tibetan Plateau and the Indian Plain, ranging between 0 and $50 \mathrm{~mm} \mathrm{month}^{-1}$ over these regions. During this period of the year, precipitation is higher over the Himalaya, in particular in the western and the eastern part of the mountain range, where it can reach several hundreds of $\mathrm{mm}$ month $^{-1}$ depending on the dataset. Precipitation reaches also relatively high values of around $100 \mathrm{~mm} \mathrm{month}^{-1}$ in Bangladesh and regions located at the east side of this country.

Similar to the monsoon period, MAR allows describing more accurately the spatial heterogeneity of precipitation due to its high spatial resolution in comparison with the ERAINTERIM. However, there is again a dry bias in the southern foothills of the Himalaya, which is much more pronounced in the MAR simulation (Fig. 4b) than in the ERA-INTERIM reanalysis (Fig. 4d). APHRODITE shows very low precipitation rates in the northern part of the Himalayan Mountains, which is possibly due to an underestimation of solid precipitation from the rain gauges used within this network. Indeed, higher precipitation is commonly estimated in this region with TRMM, ERA-INTERIM and MAR (Fig. 4b, d and f). However, in the western and the eastern parts of the Himalaya, the estimation of precipitation varies widely according to the different sources: It has values between 100 and $200 \mathrm{~mm} \mathrm{month}^{-1}$ in the ERA-INTERIM, between 100 and $400 \mathrm{~mm} \mathrm{month}^{-1}$ in the MAR simulation and between 100 and $500 \mathrm{~mm} \mathrm{month}^{-1}$ in the TRMM data. TRMM estimation of precipitation is highest in these regions in particular in comparison with the MAR simulation (Fig. 4h).

\section{Snow cover and snowfall}

\subsection{Snow cover estimation from satellites and models}

Using remote-sensing data, it is possible to evaluate the Snow Cover Extent (SCE) from 1960 to present day. For example, the Interactive Multisensor Snow and Ice Mapping System (IMS) data is available for the whole Northern Hemisphere, and is distributed by the NOAA (NOAA, NSIDC, 2004). Recent satellite imagery has been found to be a very useful tool to describe SCE (Derksen and Brown, 2012) and is therefore widely used to validate models (e.g. Brutel-Vuilmet et al., 2013). Immerzeel et al. (2009) and Bookhagen and Burbank (2010) have suggested hydrological applications using remote sensing over the Himalaya. However, Snow Water Equivalent (SWE) cannot be estimated accurately with satellite data, in particular over mountainous regions (Takala et al., 2011). Therefore, SWE remains a variable quite difficult to estimate at global and regional scales. Until today, local observations are the only way to accurately measure SWE. Therefore, it is quite difficult to estimate SWE at large scales, as it can be spatially highly variable, in particular 


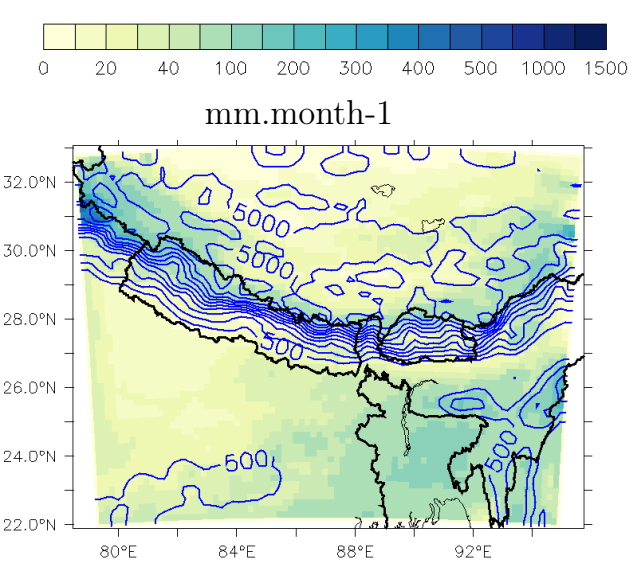

(a) MAR

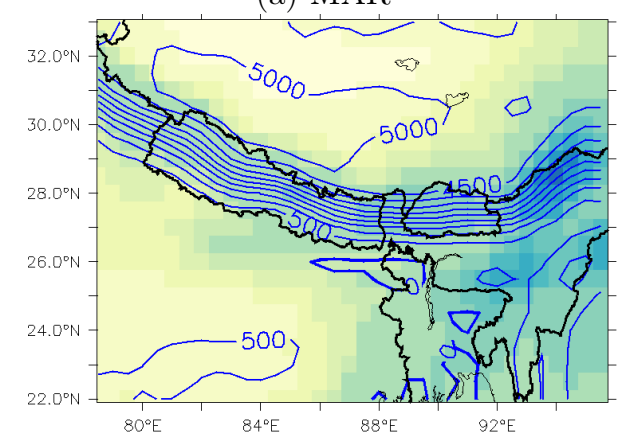

(c) ERA

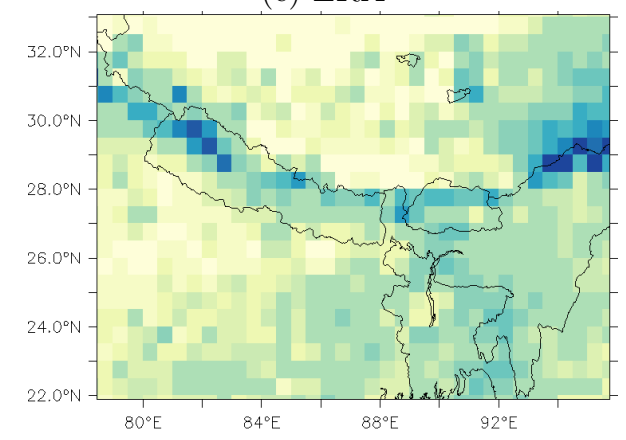

(e) TRMM

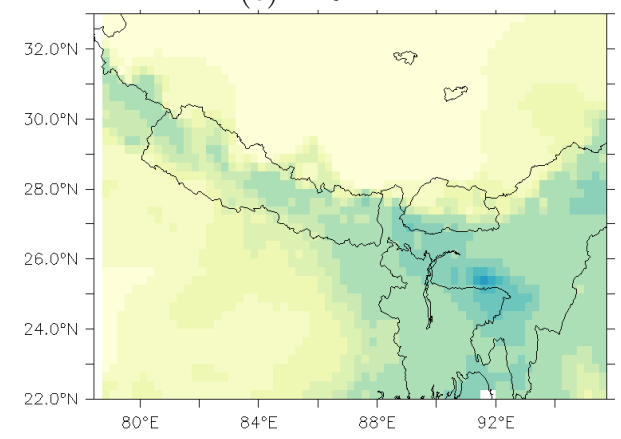

(g) APHRO

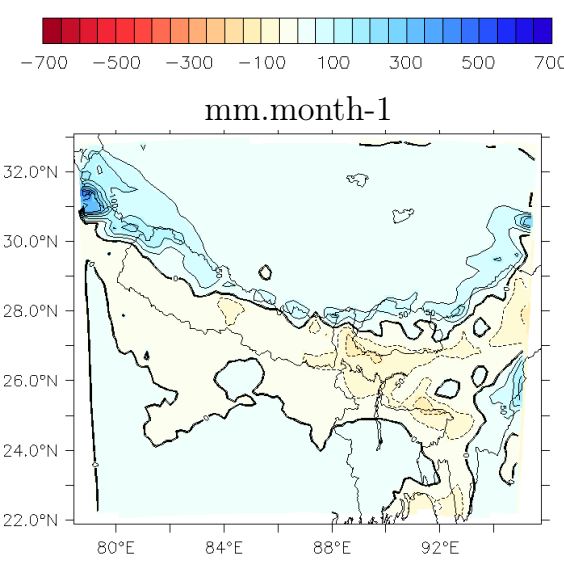

(b) MAR-APHRO

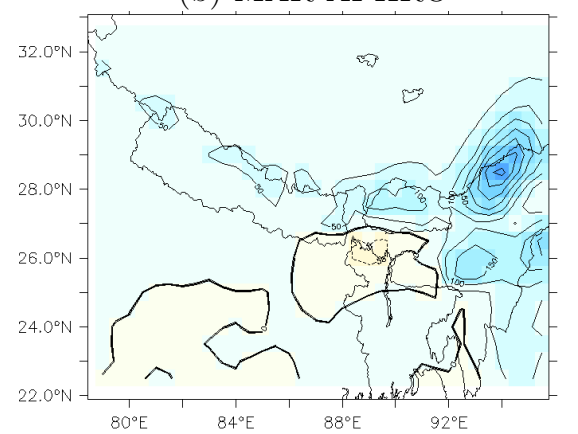

(d) ERA-APHRO

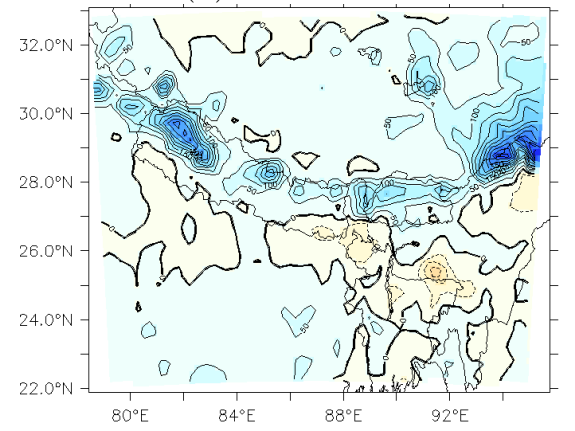

(f) TRMM-APHRO

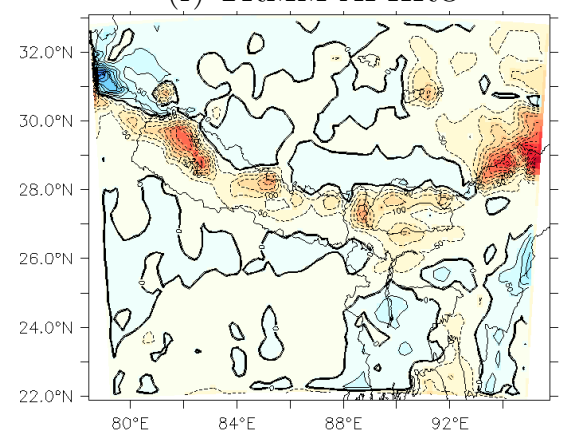

(h) MAR-TRMM

Fig. 4. Extra-monsoon (ONDJFMAM) 2001-2002 precipitation (mm month ${ }^{-1}$ ): (a) simulated with MAR, (c) estimated from ERAINTERIM, (e) evaluated from TRMM, and (g) observed with APHRODITE network. Figures in the right column correspond to the differences (b) MAR-APHRODITE, (d) ERA-INTERIM-APHRODITE, (f) TRMM-APHRODITE, and (h) MAR-TRMM. 


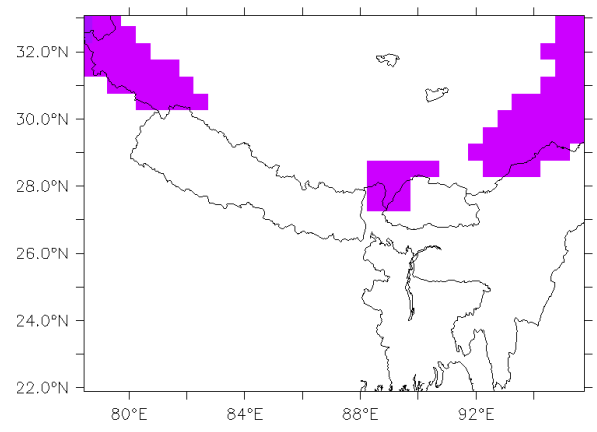

(a) SWE Era-interim

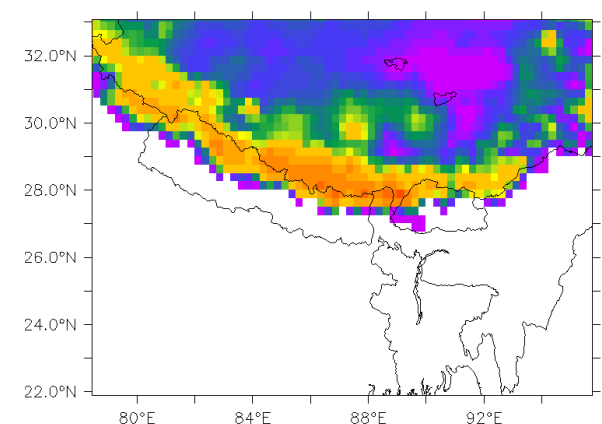

(b) SWE CMC

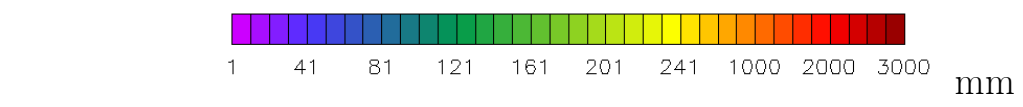

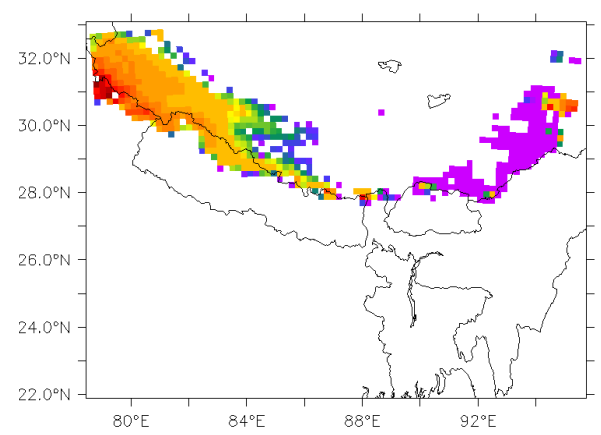

(c) SWE MAR

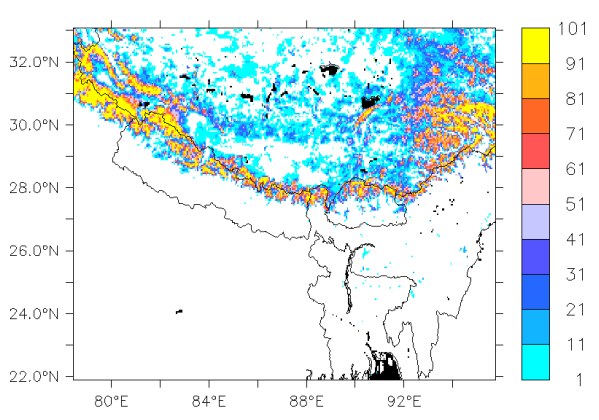

(d) MODIS Snow cover fraction (\%)

Fig. 5. April 2001 Snow Water Equivalent (mm): (a) estimated from the ERA-INTERIM, (b) evaluated by the Canadian Meteorological Centre (CMC) and (c) simulated with MAR. (d) shows the Snow Cover Extent (SCE) observed with MODIS for the same period.

in regions with a complex topography. In the Himalaya, the maximum of SCE occurs at the beginning of spring (Bookhagen and Burbank, 2010). Figure 5 shows the SWE equivalent in April 2001 estimated from the ERA-INTERIM (Fig. 5a), analysed from the Canadian Meteorological Center (CMC, Brasnett, 1999) and modelled with MAR (Fig. 5c). For validation purposes, we show in Fig. 5d the SCE observed with MODIS satellite in April 2001 with regions of SCE higher than $50 \%$ in yellow to red. To check the ability of a model to simulate the snow cover, we expect it to successfully simulate snow where MODIS data shows SCE values higher than $50 \%$. Elsewhere, the major part of the surface is free of snow, and a model that does not consider sub grid snow fraction is not supposed to simulate presence of snow. As mentioned previously, MODIS, CMC and ERA-INTERIM products are described more in detail in Table 1.

The MODIS SCE shown for April 2001 is typical for the present-day spring SCE, as it is comparable to the 20002008 spring average shown by Immerzeel et al. (2009, see Fig. 4). Regarding Fig. 5a, we clearly see that the coarse resolution of the model used to construct the ERA-INTERIM reanalysis does not allow describing SWE accurately. Dutra et al. (2011) found a strong underestimation of snow cover in the ECMWF model, particularly pronounced over mountainous regions due to the non-resolved topography. Moreover, Dee et al. (2011) indicated that SWE in the ERA-INTERIM must be taken very carefully due to the difficulty to assimilate local observations of SWE in a reanalysis product. The CMC product is a gridded SWE estimation for the whole Northern Hemisphere. It is based on a surface model simulating snowfall and snowmelt with precipitation and temperature provided from atmospheric analysis. When available, snow depth local measurements are used to correct the CMC model outputs using statistical methods (kriging). The lack of observations is certainly responsible for the strong errors pointed out in this product comparing it with the MODIS SCE observation in the Himalayan region. The CMC dataset shows surprisingly homogeneous values of SWE over the whole Himalayan mountain range and clearly overestimates the SWE in the southern part of Tibet (Fig. $5 b$ and d). Snow cover appears to be better represented in the MAR simulation (Fig. 5c) than in the ERA-INTERIM and in the CMC estimations. Overall, our model simulates a snow cover that is in agreement with MODIS data in April 2001.

The snow cover duration modelled with MAR is also comparable with those measured by the IMS satellite data 


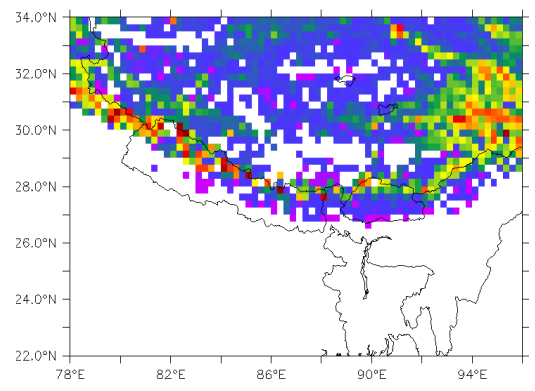

(a) OBS 2000-2001

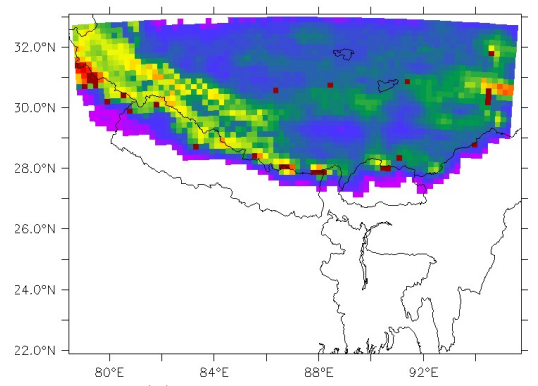

(c) MAR 2000-2001

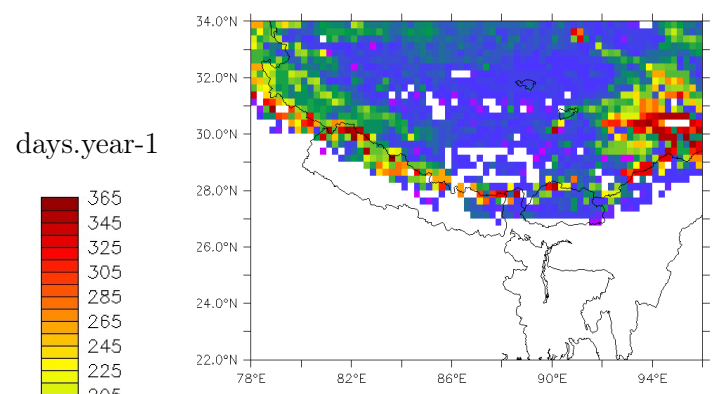

(b) OBS 2001-2002

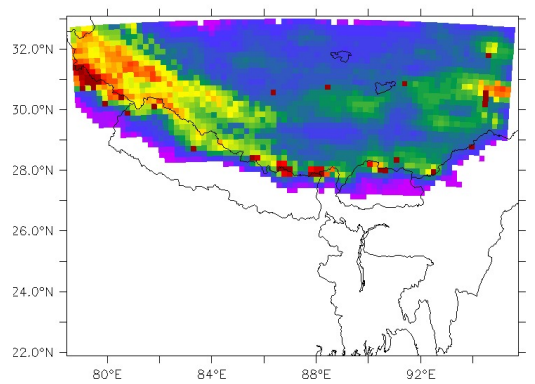

(d) MAR 2001-2002

Fig. 6. Snow cover duration: (a) 2000-2001 and (b) 2001-2002 IMS observation (NSIDC, 2004); (c) 2000-2001 and (d) 2001-2002 MAR simulation. Annual values are computed from October to October.

(NOAA, NSIDC, 2004) for the years 2000-2001 and 20012002 (Fig. 6). Regarding modelled and observed snow cover duration for these two years, three main characteristics can be pointed out: (1) snow cover duration is very heterogeneous along the Himalayan mountain range, with values ranging from 0 to 365 days, because of the high spatial variability of the altitude. (2) The snow cover duration exceeds half of the year over large areas of western and eastern parts of the Himalayan mountain range. (3) Snow cover duration is very low over the Tibetan Plateau, often ranging between 0 and 10 days per year, and reaching a hundred of days in only small areas of this region.

A strong bias in the MAR simulation is visible in the eastern part of Himalaya, where the snow cover duration is largely underestimated (Figs. 5c and 6). Part of this bias is certainly explained by an underestimation of snowfall. Therefore, the high precipitation rates found in TRMM and ERA-INTERIM in this region are certainly more realistic compared to the APHRODITE network and the MAR simulation (see Fig. 4). In the central and the western parts of our domain, we found a better agreement between modelled and observed snow cover duration patterns (Fig. 6), providing confidence in the snowfall simulated with MAR. In particular, we distinguish in our simulation two parallel and longitudinal areas of the western part of our domain with high values of snow cover duration. These are induced by local topography characteristics, and are clearly visible both in MODIS (Fig. 5d) and IMS (Fig. 6a and b) observations. Such a characteristic pattern is reproduced with the MAR model due to its high spatial resolution. Nevertheless, it is quite challenging to estimate the precipitation rate in this region. Even with a quite realistic pattern of snow cover in central and western Himalaya, the simulated snow cover duration is relatively over-estimated in comparison with the IMS observation, which may be induced by too strong levels of snowfall in the MAR simulation. Applying RCMs in this region, Dimri and Niyogi (2012) and Dimri et al. (2013) have found also high precipitation rates in this region in comparison with the gridded estimation of the APHRODITE network. The high levels of snow cover extent observed during the end of the winter in this region are necessarily induced by snowfall occurring in fall or in winter. Therefore, in agreement with Dimri and Niyogi (2013) and Dimri et al. (2013), we also suggest that APHRODITE data underestimate precipitation in this region. Finally, the real precipitation rates in these regions are likely higher than the APHRODITE estimation and lower than those simulated with MAR.

According to the observations (Fig. 6a and b), the snow cover extent is larger in spring 2001 than in spring 2002 in western and central Himalaya. This is the contrary in the eastern part of the Himalaya, where snow cover is reduced in spring 2001 in comparison with spring 2002. Even if two years of simulation is a period too short to discuss the ability of our model to simulate the snow cover interannual variability, we see these snow cover variations from spring 2001 to spring 2002 to be partly reproduced in our simulation. In a further study with the possibility to perform longer simulations, we can therefore expect our RCM to be able to simulate the snow cover interannual variability. 


\subsection{Simulated snowfall}

As there are very few local observations, it is very difficult to estimate snowfall rates in the Himalaya. Moreover, such observations are generally available at relatively low altitudes, where precipitation is rather liquid than solid. In addition, the rain gauges available at higher altitudes are generally not able to measure the solid fraction of precipitation. Facing these uncertainties, Shrestha et al. (2012) reconstructed snowfall at the scale of a high elevation basin of the Nepal Himalaya using snow depth measurements. They corrected the precipitation data in order to simulate the snow depth observed at a $5035 \mathrm{~m}$ a.s.l. site, multiplying rain gauge data by a factor 2.5 . Also in central Himalaya, Lang and Barros (2004) found in winter observational data a decrease of precipitation with the altitude, which is certainly an artefact caused by rain gauge errors. According to their study, accounting for snowfall implies total precipitation rates equivalent at all altitudes during the extra-monsoon period. During the monsoon, they suggested however the precipitation rates to reach their highest values at low elevation. Winiger et al. (2005) analysed snow depth measurements and meteorological data in the western Himalaya. They found an increase of the annual precipitation with altitude, reaching a ratio of six between the precipitation at $200 \mathrm{~m}$ and $4500 \mathrm{~m}$. Up to $4500 \mathrm{~m}$, they found the snowfall contribution to exceed $80 \%$ of the total annual precipitation. Bookhagen and Burbank (2010) analysed the hydrological budget differences of western and eastern Himalayan basins. They showed that two third of the precipitation in western basins are associated to the westerly cyclones, whereas $80 \%$ of the moisture is coming from the summer monsoon in central Himalaya. In addition, they found snowmelt to consist in $50 \%$ of the hydrological budget of western basins, $25 \%$ of eastern basins and $20 \%$ or less elsewhere. With similar approaches, glaciological studies found that snow accumulation in western Himalaya are mainly associated with the westerly cyclones whereas the monsoon plays a large source of snow accumulation for the glaciers in central Himalaya (Bolch et al., 2012; Wagnon et al., 2013). However, snowfall cannot be directly estimated from these studies, which only allow to determine snow melting rates or glacier surface mass balances, mixing both snow accumulation, melting, and sublimation. Finally, in a context with very few snowfall local observations, models appear to be the only tool to diagnose snowfall in the Himalaya. Hence, even if RCMs show significant biases simulating precipitation (see Sect. 5), they appear very useful to estimate the regional and seasonal distribution of snowfall in the Himalaya.

ERA-INTERIM snowfall estimation (Fig. 7a and b) seems to be very small regarding the quite long observed snow cover duration (Fig. 6a and b) in the Himalaya in the monsoon and the extra-monsoon period of 2001-2002. Due to the coarse resolution of this reanalysis, we suspect it to strongly underestimate snowfall rates. The relatively high resolution of our RCM allows a more realistic representation of the topography (see the iso-lines in Fig. 7), which appears essential to correctly describe both the rate and the spatial distribution of snowfall in the Himalayan mountain areas. In our simulation, the Indian monsoon brings high levels of snowfall in central Himalaya, with values ranging from 100 to $700 \mathrm{~mm} \mathrm{month}^{-1}$ during the summer 2001 (Fig. 7c). Note that we generally do not simulate snowfall at altitudes lower than $4500 \mathrm{~m}$ during this period of the year. Higher reliefs cannot be represented in the ERA-INTERIM due to the coarse resolution of the ECMWF model, which explains that we found negligible snowfall rates in this reanalysis during the monsoon period. Summer snowfall is slightly decreasing when going eastward and westward along the Himalaya. This is contrary to the extra-monsoon period, when the higher levels of snowfall are simulated in western and eastern $\mathrm{Hi}$ malaya. During the 2001-2002 snow cover season, snowfall average rates do not exceed $100 \mathrm{~mm} \mathrm{month}^{-1}$ in most of the mountains of eastern Nepal, Sikkim and Bhutan, whereas it often reaches values between 200 and $400 \mathrm{~mm} \mathrm{month}^{-1}$ in the most western part of the domain of our study. In western Nepal, the limit rain/snow drops to $3000 \mathrm{~m}$ altitude on average during this season. Overall, Fig. $7 \mathrm{c}$ and d show very heterogeneous snowfall distribution, with maximum values simulated over high mountains.

\subsection{Regional characteristics of snow cover accumulation}

The temperature in the Himalayan region shows a seasonal cycle typical of temperate regions, with low temperatures in winter and high temperatures in summer. On the contrary, SWE, rainfall and snowfall follow much more complex seasonal evolutions, which have been characterised separately for 4 mountainous subsectors of our domain of simulation in Fig. 8 (subsectors 1 to 4 concern regions with an altitude exceeding $2500 \mathrm{~m}$ a.s.l.). The western part of our domain, centred on the mountains of western Nepal (Fig. 8, subsector 1 ), sees a pronounced seasonal cycle of snow cover. In this region, snow depth reaches high values at the beginning of spring, with a maximum varying by a factor of 2 between 2001 and $2002(150 \mathrm{~mm}$ for the first year and $300 \mathrm{~mm}$ for the second year on average). Largest values of snow depth are simulated at the most western part of this subsector, which receives high amount of snowfall both during the monsoon period (JJAS) and during the winter and the pre-monsoon pe$\operatorname{riod}(\mathrm{JFMA})$. Due to the relatively high temperature in summer, snow accumulated during this period of the year melts quickly. In this region, most of the precipitation occurs as snowfall, even during the summer (Fig. 8, histogram for subsector 1). Moreover, the dry season is relatively short (OND) and is not very pronounced in Subsector 1 . This is not the case in central Himalaya (eastern part of Nepal and Bhutan, see Fig. 8, subsector 2), where precipitation rates are very low during a long period extended from November to March. In this region, snowfall and rainfall rates increase in spring, 


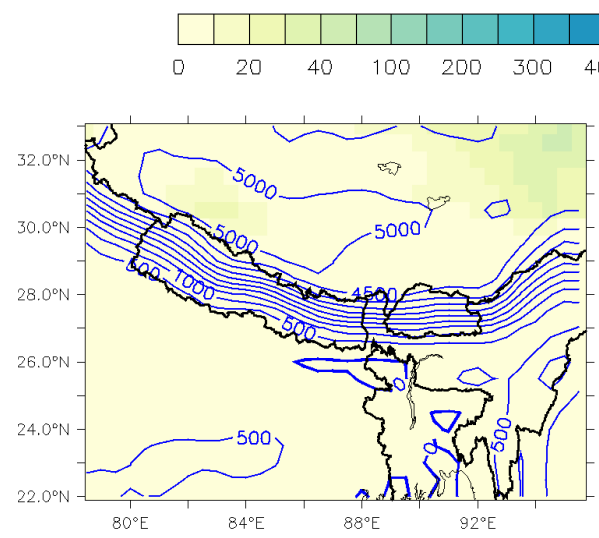

(a) JJAS 2001 Era-interim

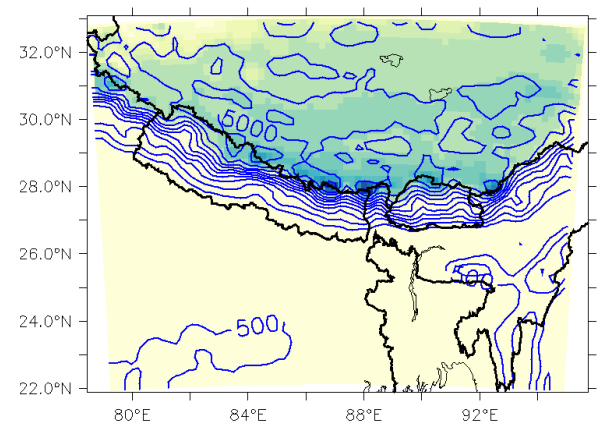

(c) JJAS 2001 MAR

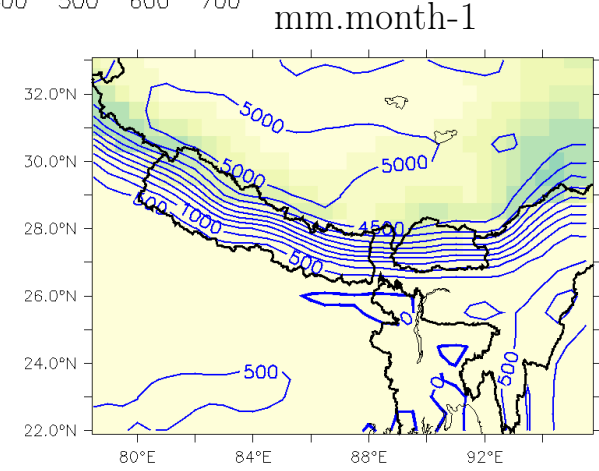

(b) ONDJFMAM 2001-2002 Era-interim

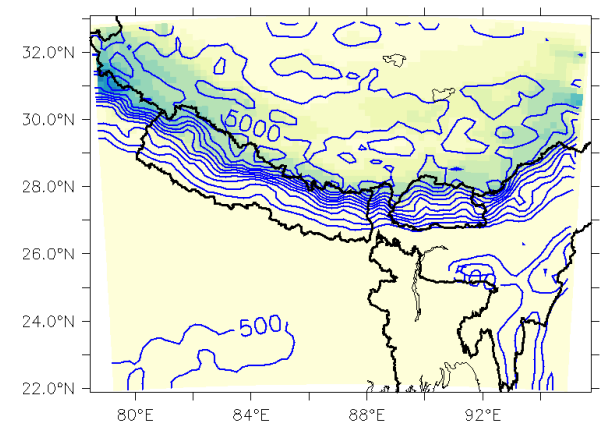

(d) ONDJFMAM 2001-2002 MAR

Fig. 7. Snowfall (mm month ${ }^{-1}$ ): Estimated with ERA-INTERIM (a) during monsoon (JJAS) 2001, (b) during extra-monsoon period (ONDJFMAM) 2001-2002; simulated with MAR (a) during monsoon (JJAS) 2001, (b) during extra-monsoon period (ONDJFMAM) 2001-2002. $500 \mathrm{~m}$-spaced iso-lines show the model topography.

both of them reaching very high values during the monsoon period (Fig. 8, histogram for subsector 2). Here, snow depth does not have a pronounced cycle. It is quite variable from one year to another, due to the randomness of the association of snowfall occurrence and temperature variations: very low snowfall rates during fall 2000 and winter 2001 (not shown) induce very low values of snow depth during this cold period (from October to March). During 2001, the maximum snow depth is simulated in fall, when the end of the monsoon brings snow, which forms a persistent snowpack due to the low temperature during this season. In 2002, we simulated two maxima of snow depth: the first one occurs at the end of the winter, when snowfall occurs particularly early while the still low temperature limits the melting. Despite the increase of snowfall during spring and summer, snow depth is decreasing on average over this subsector because of the increase of temperature. Finally, snow depth reaches a second maximum in fall 2002, when the last precipitation of the monsoon brings snow during the already cold period. In this subsector 2, the snow depth is spatially very variable, with maximum values modelled over high mountains. Elsewhere, snow depth is quite limited, inducing values over this subsector never exceeding $80 \mathrm{~mm}$ on average for the three years of simulation. As in the west of Nepal, snow depth shows a pronounced annual cycle in eastern Himalaya, with a maximum occurring at the beginning of spring (see Fig. 8, subsector 3). In this region, snow cover evolution is similar to the evolution simulated for the first subsector. However, we have to be very careful regarding our simulation in this region, as the under-estimation of snow cover extent and duration (Figs. 5 and 6) is certainly explained by a snowfall underestimation (Figs. 3 and 4). Still, the annual cycle of precipitation in eastern Himalaya shows a similar pattern as those simulated in central Himalaya, with a summer maximum induced by the monsoon, generating similar rates of snowfall and rainfall on average over subsector 3 (Fig. 8, histogram for subsector 3). The Tibetan Plateau appears as a very dry region, with precipitation rates two times lower in comparison with those simulated in Himalaya (Fig. 8, histogram for subsector 4). In this region, precipitation occurs mainly as snowfall, and snow depth is highly variable, both spatially and temporally. On average over the three years, simulated values vary between 0 and $10 \mathrm{~mm}$. As in central Himalaya, snowfall is very low from October to 


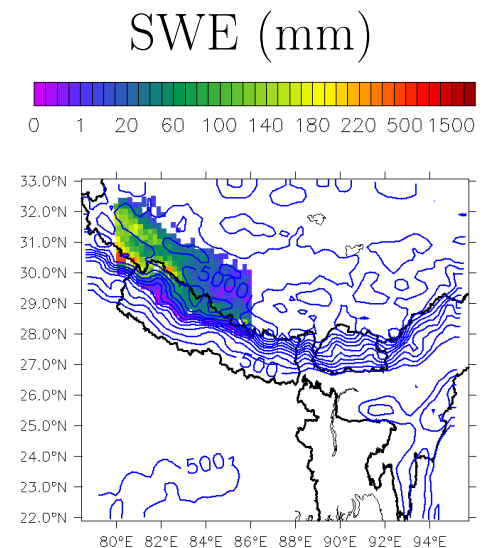

\section{Mean SWE (mm)}

Monthly precip. (mm)

(1)
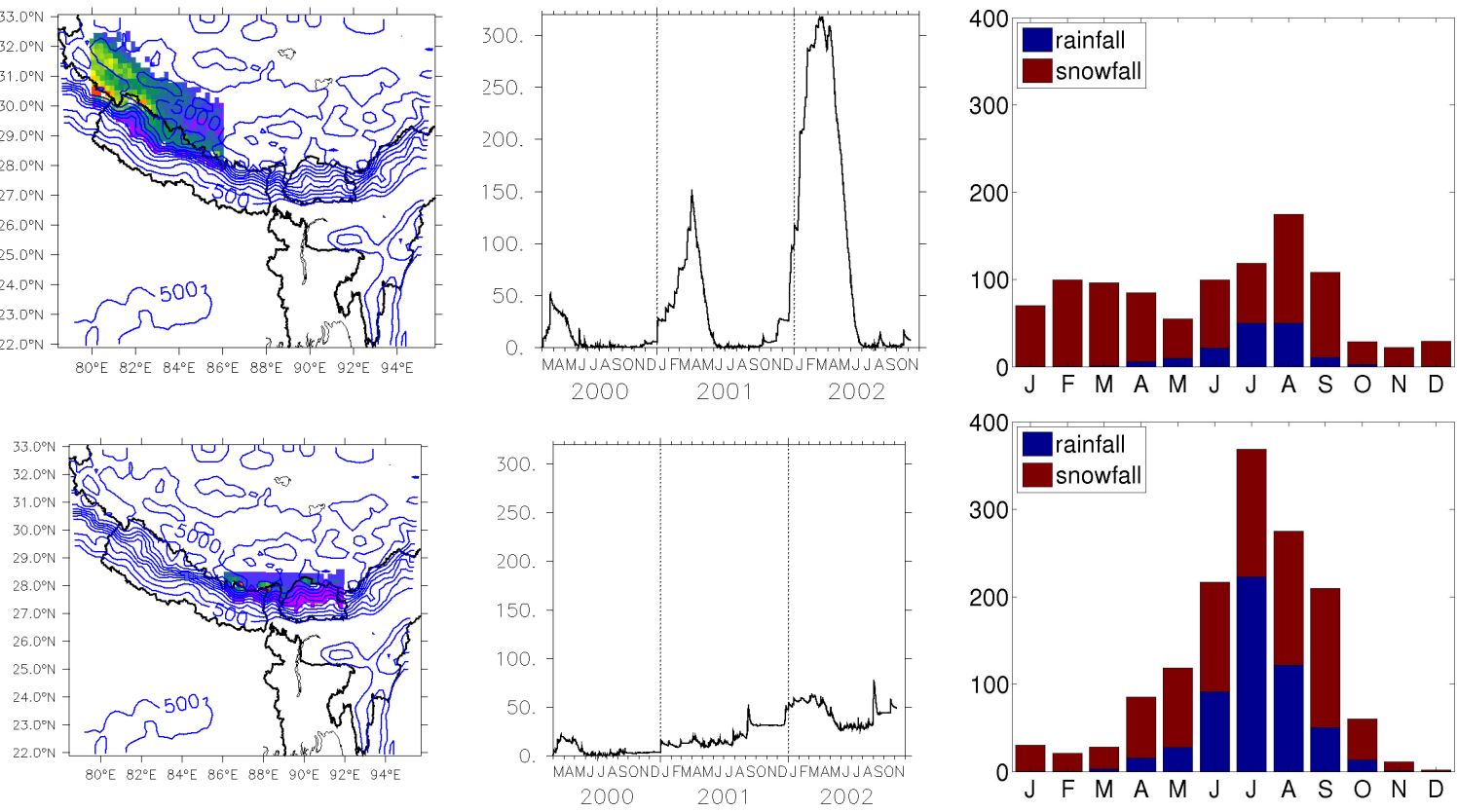

(2)
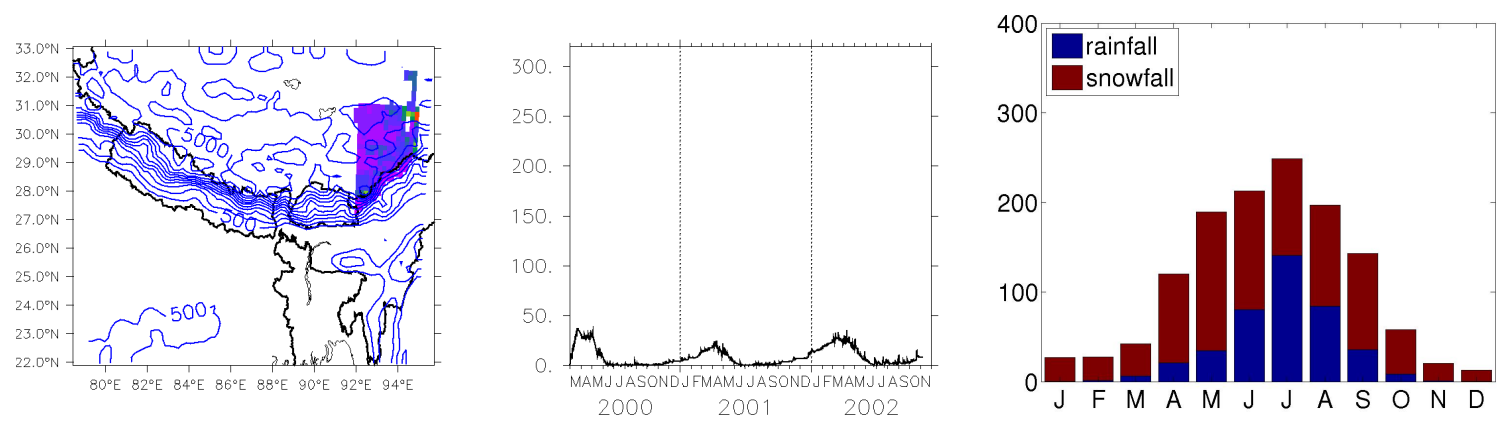

(3)
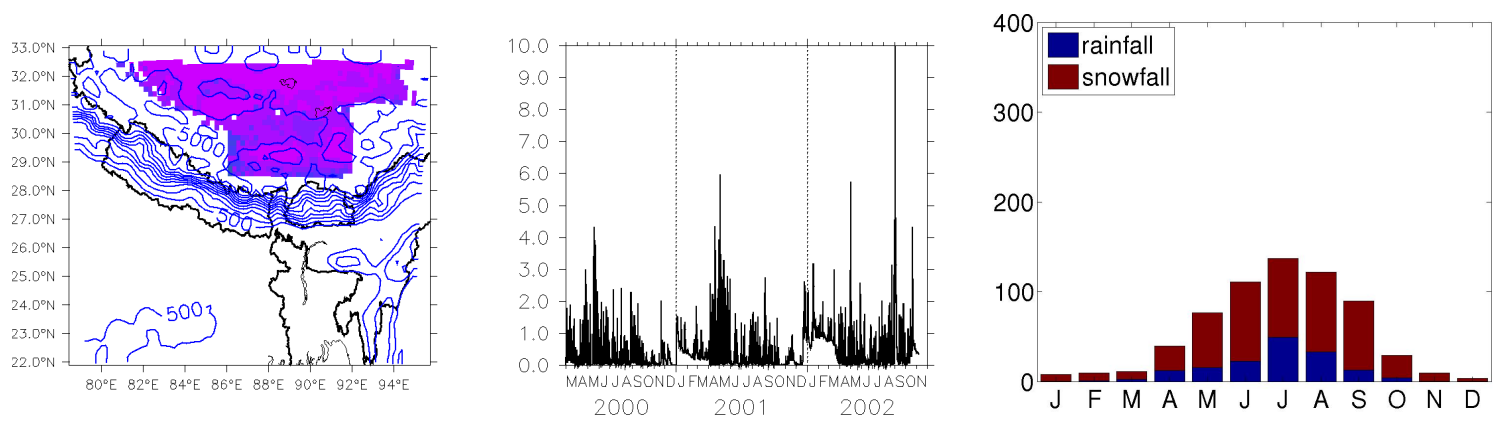

Fig. 8. Snow Water Equivalent (SWE, mm, first column), mean SWE (mm, second column) and annual cycle of precipitation (third column, monthly means of snowfall and rainfall over 2000-2002) for the domain areas coloured in the first column (subsectors numbered from 1 to 4, all altitudes exceed $2500 \mathrm{~m}$ a.s.1.).

March, and reaches higher values during spring and summer. It is during these seasons that snow depth reaches its maximum. However, in our simulation, the surface of the Tibetan Plateau is never snow covered during more than several days in spring and summer. Here, the only period of the year when snow cover remains during several months is extended from December to March, but with values of snow depth generally not exceeding $1 \mathrm{~mm}$ on average over the subsector 4 . 


\section{Conclusions}

We applied a RCM over Himalaya to simulate precipitation and snow cover from March 2000 to December 2003. Due to its high spatial resolution, our RCM appears very useful to describe the spatial variability of precipitation and snow cover over the Himalaya, which cannot be correctly simulated with coarse gridded global atmospheric models. RCMs are particularly useful to simulate the atmospheric circulation over mountainous areas, which can be strongly affected by the topography, both locally and regionally. Nevertheless, it appears quite challenging to estimate the real precipitation rates in the Himalaya: on one hand, observational data are particularly scarce, and rain gauges are generally not adapted to measure snowfall. On the other hand, models are far to be perfect and show significant biases, especially in terms of precipitation. Still, local observations provide a correct estimation of precipitation at the foothill of the Himalaya, where there is a relatively high density of rain gauges. Comparing our simulation with these observations in this area, we found our RCM to underestimate precipitation. We further expect a significant underestimation of precipitation in the observational datasets at high altitude. Therefore, it is more complicated to validate model outputs in these areas. As snow cover extent is well estimated with satellite products, checking the ability of models to simulate snow cover is a way to partially analyse its performance in terms of snowfall description. In particular, our MAR simulation clearly underestimates snowfall in the eastern part of the Himalaya, whereas it appears more correct in central Himalaya and in western Nepal. Finally, we expect our model to provide a first approximation of snowfall in these high altitude areas. Based on the simulations, we characterised snow accumulation in the Himalaya, which differs widely along this mountain range: snowfall can occur during all seasons in western Himalaya, due to both summer monsoon and mid-latitude low pressure systems bringing moisture in this region. In central Himalaya and in the Tibetan Plateau, there is a marked dry season, occurring from October to March. The snow cover does not have a pronounced seasonal cycle in these regions, as it depends on both the duration of the monsoon - quite variable from one year to another - and on the unlikely but possible occurrence of snowfall during the extra-monsoon period. Our work provided a first regional description of snow cover and snowfall in the Nepalese Himalaya. Improving the physical schemes of our RCM, we hope in further studies to decrease the biases highlighted in this study, and to perform simulations over longer period to analyse in more detail the snowfall inter-annual variability over the Himalaya. Multiannual applications of this model could be also used to study the poorly known interactions of the East Asian and the Indian Summer Monsoons with the snow cover extent over the Himalaya and the Tibetan Plateau.
Acknowledgements. This work was supported by Agence Nationale de la Recherche under contract ANR-09-CEP-005-02/PAPRIKA. We would like to thank the "Institut du Développement et des ressources en Informatique" (IDRIS, CNRS), and the "CIMENT" resources (UJF) for providing computer time for the simulations presented in this paper. The figures have been prepared with Ferret free software. We thank the National Snow and Ice Data Centre (NSIDC, Boulder, CO) for providing MODIS Snow cover data.

Edited by: A. Langousis

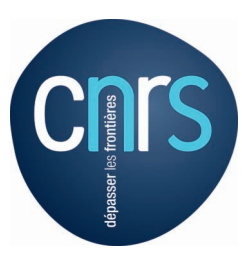

The publication of this article is financed by CNRS-INSU.

\section{References}

Akhtar, M., Ahmad, N., and Booij, M. J.: Use of regional climate model simulations as input for hydrological models for the Hindukush-Karakorum-Himalaya region, Hydrol. Earth Syst. Sci., 13, 1075-1089, doi:10.5194/hess-13-1075-2009, 2009.

Archer, D. R. and Fowler, H. J.: Spatial and temporal variations in precipitation in the Upper Indus Basin, global teleconnections and hydrological implications, Hydrol. Earth Syst. Sci., 8, 47-61, doi:10.5194/hess-8-47-2004, 2004.

Bechtold, P., Basile, E., Guichard, F., Mascart, P., and Richard, E.: A mass flux convection scheme for regional and global models, Q. J. Roy. Meteorol. Soc., 127, 869-886, 2001.

Bolch, T., Kulkarni, A., Kääb, A., Huggel, C., Paul, C., Cogley, J. G., Frey, H., Kargel, J. S., Fujita, K., Scheel1, M., Bajracharya, S., and Stoffel, M.: The State and fate of Himalayan glaciers, Science, 336, 6079, 310-314, doi:10.1126/science.1215828, 2012.

Bookhagen, B. and Burbank, D. W.: Toward a complete Himalayan hydrological budget: Spatiotemporal distribution of snowmelt and rainfall and their impact on river discharge, J. Geophys. Res., 115, F03019, doi:10.1029/2009JF001426, 2010.

Brasnett B.: A global analysis of snow depth for numerical weather prediction, J. Appl. Meteorol., 38, 726-740, 1999.

Brun, E., David, P., Sudul, M., and Brunot, G.: A numerical model to simulate snow-cover stratigraphy for operational avalanche forecasting, J. Glaciol., 38, 13-22, 1992.

Brutel-Vuilmet, C., Ménégoz, M., and Krinner, G.: An analysis of present and future seasonal Northern Hemisphere land snow cover simulated by CMIP5 coupled climate models, The Cryosphere, 7, 67-80, doi:10.5194/tc-7-67-2013, 2013.

Dee, D. P., Uppala, S. M., Simmons, A. J., Berrisford, P., Poli, P., Kobayashi, S., Andrae, U., Balmaseda, M. A., Balsamo, G., Bauer, P., Bechtold, P., Beljaars, A. C. M., van de Berg, L., Bidlot, J., Bormann, N., Delsol, C., Dragani, R., Fuentes, M., Geer, A. J., Haimberger, L., Healy, S. B., Hersbach, H., Holm, E. V., Isaksen, L., Kollberg, P., Kohler, M., ao Matricardi, M., McNally, A. P., Monge-Sanz, B. M., Morcrette, J.-J., Park, B.-K., Peubey, C., de Rosnay, P., Tavolato, C., Thépaut, J.-N., and Vitart, F.: The ERA-Interim reanalysis: configuration and performance of the data assimilation system, Q. J. Roy. Meteorol. Soc., 137, 553597, doi:10.1002/qj.828, 2011. 
De Ridder, K. and Schayes, G.: The IAGL land surface model, J. Appl. Meteorol., 36, 167-183, 1997.

Derksen, C. and Brown, R.: Spring snow cover extent reductions in the 2008-2012 period exceeding climate model projections, Geophys. Res. Lett., 39, L19504, doi:10.1029/2012GL053387, 2012.

Dimri, A. P. and Niyogi, D.: Regional climate model application at subgrid scale on Indian winter monsoon over the western Himalayas, Int. J. Climatol., 33, 2185-2205, doi:10.1002/joc3584, 2013.

Dimri, A. P., Yasunari, T., Wiltshire, A., Kumar, P., Mathison, C., Ridley, J., and Jacob, D.: Application of regional climate models to the Indian winter monsoon over the western Himalayas, Sci. Total Environ., online first, doi:10.1016/j.scitotenv.2013.01.040, 2013.

Dutra, E., Kotlarski, S., Viterbo, P., Balsamo, G., Miranda, P. M. A., Schär, C., Bissolli, P., and Jonas, T.: Snow cover sensitivity to horizontal resolution, parameterizations, and atmospheric forcing in a land surface model, J. Geophys. Res., 116, D21109, doi:10.1029/2011JD016061, 2011.

Ebert, E. E. and Curry, J. A.: A parameterization of ice cloud optical properties for climate models, J. Geophys. Res., 97, 3831-3836, 1992.

Feng, J. and Fu, C.: Inter-comparison of 10-year precipitation simulated by several RCMs for Asia, Adv. Atmos. Sci., 4, 531-542, 2006.

Fouquart, Y. and Bonnel, B.: Computations of solar heating of the Earth's atmosphere: a new parameterization, Beitraege Phys. Atmos., 53, 35-62, 1980.

Fu, C., Wang, S., Xiong, Z., Gutowski, W. J., Lee, D.-K., McGregor, J. L., Sato, Y., Kato, H., Kim, J.-W., and Suh, M.-S.: Regional climate model intercomparison project for Asia, B. Am. Meteorol. Soc., 86, 257-266, 2005.

Gallée, H.: Simulation of the mesocyclonic activity in the Ross Sea, Antarctica, Mon. Weather Rev., 123, 2051-2069, 1995.

Gallée, H. and Schayes, G.: Development of a three-dimensional meso-gamma primitive equation model: katabatic winds simulation in the area of Terra Nova bay, Antarctica, Mon. Weather. Rev., 122, 671-685, 1994.

Gallée, H., Guyomarch, G., and Brun, E.: Impact of snowdrift on the Antarctic ice sheet surface mass balance: possible sensitivity to snow-surface properties, Bound.-Lay. Meteorol., 99, 1-19, 2001.

Gallée, H., Moufouma-Okia, W., Bechtold, P., Brasseur, O., Dupays, I., Marbaix, P., Messager, C., Ramel, R., and Lebel, T.: A high resolution simulation of a West African rainy season using a regional climate model, J. Geophys. Res., 109, D05108, doi:10.1029/2003JD004020, 2004.

Gallée, H., Peyaud, V., and Goodwin. I.: Simulation of the net snow accumulation along the Wilkes Land transect, Antarctica, with a regional climate model, Ann. Glaciol., 41, 17-22, 2005.

Goodison, B. E., Louie, P. Y. T., and Yang, D.: WMO Solid Precipitation Measurement Intercomparison. Final Report, WMO TDNo. 872, World Meteorological Organization, Geneva, 212 pp., 1998.

Hall, D. K., Salomonson, V. V., and Riggs, G. A.: MODIS/Terra Snow Cover Monthly L3 Global 0.05Deg CMG, Version 5. Version 5.0., Boulder, Colorado, USA: National Snow and Ice Data Center, 2006.
Immerzeel, W. W., Droogers, P., de Jong, S. M., and Bierkens, M. F. P.: Large-scale monitoring of snow cover and runoff simulation in Himalayan river basins using remote sensing, Remote Sens. Environ., 113, 40-49, 2009.

Kummerow, C., Barnes, W., Kozu, T., Shiue, J., and Simpson, J.: The Tropical Rainfall Measuring Mission (TRMM) Sensor Package, J. Atmos. Ocean. Tech., 15, 809-817, doi:10.1175/15200426(1998)015<0809:TTRMMT>2.0.CO;2, 1998.

Kummerow, C., Simpson, J., Thiele, O., Barnes, W., Chang, A. T. C., Stocker, E., and Nakamura, K.: The status of the Tropical Rainfall Measuring Mission (TRMM) after two years in orbit, J. Appl. Meteorol., 39, 1965-1982, doi:10.1175/15200450(2001)040<1965:TSOTTR>2.0.CO;2, 2000.

Lang, T. and Barros, A. P.: Winter Storms in the central Himalayas, J. Meteorol. Soc. Jpn., 82, 829-844, 2004.

Lefebre, F., Gallée, H., Ypersele, J. P., and Greuell, W.: Modeling of snow and ice melt at ETH camp (West Greenland): a study of surface albedo, J. Geophys. Res., 108, 4231, doi:10.1029/2001JD001160, 2003.

Levkov, L., Rockel, B., Kapitza, H., and Raschke, E.: 3D mesoscale numerical studies of cirrus and stratus clouds by their time and space evolution, Beitraege Phys. Atmos., 65, 35-57, 1992.

Lin, Y.-L., Farley, R. D., and Orville, H. D.: Bulk parameterization of the snow field in a cloud model, J. Appl. Meteorol., 22, 10651092, 1983.

Lucas-Picher, P., Christensen, J. H., Saeed, F., Kumar, P., Asharaf, S., Ahrens, B., Wiltshire, A., Jacob, D., and Hagemann, S.: Can regional climate models represent the Indian monsoon?, J. Hydrometeorol., 12, 849-868, 2011.

Ma, L., Zhang, T., Frauenfeld, O. W., Ye, B., Yang, D., and Qin, D.: Evaluation of precipitation from the ERA-40, NCEP-1, and NCEP-2 Reanalyses and CMAP-1, CMAP-2, and GPCP-2 with ground-based measurements in China, J. Geophys. Res., 114, D09105, doi:10.1029/2008JD011178, 2009.

Marbaix, P., Gallée, H., Brasseur, O., and van Ypersele, J.-P.: Lateral boundary conditions in regional climate models: a detailed study of the relaxation procedure, Mon. Weather Rev., 131, 461479, 2003.

Marke, T. and Hank, T.: Using a Regional Climate Model for the Simulation of Hydrologic Processes in the High Himalayan Wangchu Watershed, Geophys. Res. Abstr., EGU2009-11150, EGU General Assembly 2009, Vienna, Austria, 2009.

Maussion, F., Scherer, D., Finkelnburg, R., Richters, J., Yang, W., and Yao, T.: WRF simulation of a precipitation event over the Tibetan Plateau, China - an assessment using remote sensing and ground observations, Hydrol. Earth Syst. Sci., 15, 1795-1817, doi:10.5194/hess-15-1795-2011, 2011.

Messager, C., Gallée, H., and Brasseur, O.: Precipitation sensitivity to regional SST in a regional climate simulation during the West African monsoon for two dry years, Clim. Dynam., 22, 249-266, doi:10.1007/s00382-003-0381-x, 2004.

Meyers, M. P., Demott, P. J., and Cotton, W. R.: New primary icenucleation parameterizations in an explicit cloud model, J. Appl. Meteorol., 31, 708-721, 1992.

Morcrette, J. J.: Sur la paramétrisation du rayonnement dans les modèles de la circulation générale atmosphérique, Univ. des Sci. et Tech. de Lille. France, Thèse de Doctorat d'Etat, 373 pp., 1984. 
Morcrette, J. J.: Assessment of the ECMWF Model cloudiness and surface radiation fields at the ARM SGP site, Mon. Weather Rev., 130, 257-277, 2002.

NOAA/NESDIS/OSDPD/SSD: IMS Daily Northern Hemisphere Snow and Ice Analysis at $4 \mathrm{~km}$ and $24 \mathrm{~km}$ Resolution. Boulder, Colorado, USA: National Snow and Ice Data Centre, 2004.

Palazzi, E., von Hardenberg, J., and Provenzale, A.: Precipitation in the Hindu-Kush Karakoram Himalaya: Observations and future scenarios, J. Geophys. Res. Atmos., 118, 85-100, 2013.

Polanski, S., Rinke, A., and Dethloff, K.: Validation of the HIRHAM-simulated Indian summer monsoon circulation, Adv. Meteorol., 2010, 415632, doi:10.1155/2010/415632, 2010.

Roesch, A.: Evaluation of surface albedo and snow cover in AR4 coupled climate models, J. Geophys. Res., 111, D15111, doi:10.1029/2005JD006473, 2006.

Revenga, C., Nackoney, J., Hoshino, E., Kura, Y., and Maidens, J.: Watersheds of the world_CD, IUCN, IWMI, Ramsar, World Resources Institute, Washington, 2003.

Sabin, T. P., Raghavan, K., Ghattas, J., Denvil, S., Dufresne, J.-L., Hourdin, F., and Terray, P.: High resolution simulation of the South Asian monsoon using a variable resolution global climate model, Clim. Dynam., doi:10.1007/s00382-012-1658-8, 2012.

Shrestha, M., Wang, L., Koike, T., Xue, Y., and Hirabayashi, Y.: Modeling the spatial distribution of snow cover in the Dudhkoshi Region of the Nepal Himalayas, J. Hydrometeorol., 13, 204-222, doi:10.1175/JHM-D-10-05027.1, 2012.

Takala, M., Luojus, K., Pulliainen, J., Derksen, C., Lemmetyinen, J., Karna, J. P., Koskinen, J., and Bojkov, B.: Estimating northern hemisphere snow water equivalent for climate research through assimilation of space-borne radiometer data and groundbased measurements, Remote Sens. Environ., 115, 3517-3529, doi:10.1016/j.rse.2011.08.014, 2011.
Vanvyve, E., Hall, N., Messager, C., Leroux, S., and Ypersele, J. P.: Internal variability in a regional climate model over West Africa, Clim. Dynam., 30, 191-202, 2008.

Wagnon, P., Vincent, C., Arnaud, Y., Berthier, E., Vuillermoz, E., Gruber, S., Ménégoz, M., Gilbert, A., Dumont, M., Shea, J. M., Stumm, D., and Pokhrel, B. K.: Seasonal and annual mass balances of Mera and Pokalde glaciers (Nepal Himalaya) since 2007, The Cryosphere Discuss., 7, 3337-3378, doi:10.5194/tcd7-3337-2013, 2013.

Winiger, M., Gumpert, M., and Yamout, H.: KarakorumHindukush-western Himalaya: assessing high-altitude water resources, Hydrol. Process., 19, 2329-2338, 2005.

Yatagai, A., Kamiguchi, K., Arakawa, O., Hamada, A., Yasutomi, N., and Kitoh, A.: APHRODITE: Constructing a long-term daily gridded precipitation dataset for Asia based on a dense network of rain gauges, B. Am. Meteorol. Soc., 93, 1401-1415, doi:10.1175/BAMS-D-11-00122.1, 2012.

Yin, Z.-Y., Zhang, X., Liu, X., Colella, M., and Chen, X.: An assessment of the biases of satellite rainfall estimates over the Tibetan Plateau and correction methods based on topographic analysis, J. Hydrometeorol., 9, 301-326, doi:10.1175/2007JHM903.1, 2008. 